in dynamometer instruments and had some of the first iron-cored wattmeters built to his design which gave remarkably good performance. The simple phase shifting transformer was also designed and built, being originally intended to facilitate testing the performance of wattmeters at low power factors, and eventually this apparatus made possible his adaptation of the direct current potentiometer to the measurement of alternating potentials. This was the first self-contained instrument for this purpose, and in connexion with it he designed the first vibration galvanometer with tuning effected by variation of the magnetic control. He also gave considerable attention to accurate resistance measurement and devised a new form of standardising bridge which was a combination of the Kelvin and Carey Foster principles, and allowed of precise comparisons between standards over a wide range of values to be made with great accuracy and rapidity, and in connexion with this bridge he developed a novel and accurate ohm standard ingeniously compensated for temperature change. Some time later he designed low resistance standards with very small time constants for use in alternating current circuits.

Dr. Drysdale's activities were not, however, entirely confined to work in electrical measurements, for at one time he gave considerable attention to the testing of magnetic materials and investigated the rotary hysteresis in iron and steel and developed an ingenious permeameter for testing magnetic materials in bulk. He also contributed papers on the radiation from black-bodies and made some important determinations of the mechanical equivalent of light which were communicated to the Royal Society. To him also belongs the credit of initiating the teaching of technical optics, in what is now the Technical Optics Department of the Northampton Polytechnic Institute, and into this work he carried the same enthusiasm and originality that characterised his electrical work. He devoted much attention to the curvature method of teaching optics and devised many original methods of optical testing and the apparatus for carrying them out. When the War came his services were placed at the disposal of the Admiralty in connexion with submarine detection and destruction, and here his sound theoretical knowledge and brilliant inventiveness found considerable scope and resulted in the appointment from which he is now retiring. Dr. Drysdale is also known as the president of the Malthusian League and as the author of numerous papers on eugenies.

\section{Sir William Preece (1834-1913)}

William Henry Preece; the distinguished electrician, was born at Bryn Helen, Carnarvon, on February 15, 1834. Educated at King's College School and King's College, London, he came under the influence of Faraday at the Royal Institution and, deciding to become an electrician, in 1852 he entered the office of Edwin Clark. The following year he was appointed a junior engineer on the staff of the Electric and International Telegraph Co. and afterwards was telegraph engineer of the Channel
Islands Telegraph Co. and the London and SouthWestern Railway Co., introducing many improvements in railway signalling. In 1870 he joined the staff of the Post Office, becoming in 1892 the engineerin-chief, a position he held until 1899. His work in telephony began in 1877 and it was he who brought to England the Bell telephone with which Kelvin and Haughton gave an amusing demonstration at the Plymouth meeting of the British Association that year. As much scepticism existed regarding the capacity of the telephone, Preece arranged for the transmission of the notes of a bugle from Southampton to the Royal Institution during a lecture he delivered. A large and distinguished audience was present and at the appropriate moment Preece asked Tennyson to listen at the telephone. After doing so for a few moments, the poet remarked gruffly, "I hear nothing." Preece, catching up the telephone, after adopting a listening attitude, said, "I can hear, 'The Campbells are Coming' ", and then proceeded with his lecture, none in the audience realising that the bugler had mistaken the date, and that Preece himself, like Tennyson, had heard nothing.

Preece's work on telephony led him in 1885 to make experiments on induction signalling and in 1892 he sent messages across the Bristol Channel from Penarth to Flat Holme. His work in this direction came to an end, however, with the use of the Hertzian waves. "Strange to say," wrote Silvanus Thompson, "he entirely missed the significance of the wireless signalling by Hertzian waves shown by Lodge at the British Association meeting at Oxford in 1894, and yet when Signor Marconi arrived upon the scene in 1896 using the same method and the same devices of oscillators, spark gaps, coherers and tappers, Preece received him with open arms and put the resources of the Post Office at his disposal with results known to all the world." By the time Preece retired three years later, wireless messages were being sent across the English Channel and between some of H.M. ships. Preece, who was admitted F.R.S. in 1881, twice served as president of the Institution of Electrical Engineers and in 1898 was elected president of the Institution of Civil Engineers. He was knighted on his retirement and was afterwards consulting engineer to the Colonies. His death took place at Penrhos, Carnarvon, on November 6, 1913.

\section{Russian Ascent into the Stratosphere}

SyMPathy will be felt for the three Russians, Fedoseenko, Vasenko and Usyskin, pilot, engineer and student respectively, who met their deaths on January 30 in an attempt to investigate further the phenomena of the upper atmosphere. It was announced in the Press that a new height record of about $70,000 \mathrm{ft}$. had been established for a manned balloon, a conclusion arrived at from the record of the damaged barograph. The pressure reached, however, has not yet been published. Apparently the accident was due to heavy weather as the prime cause, for it appears that the balloon travelled about 350 miles in a south-easterly direction from Moscow in the 